\title{
Morphology of endothelial cells from different regions of the cornea of dogs
}

\author{
Paula Stieven Hünning ${ }^{*}$ - Maria Cristina Caldart de Andrade ${ }^{1} \odot$ \\ André Carissimi ${ }^{1} \odot$ João Pigatto $^{1} \odot$
}

${ }^{1}$ Faculdade de Veterinária (FAVET), Universidade Federal do Rio Grande do Sul (UFRGS), Avenida Bento Gonçalves, 9090, 91540-000, Porto Alegre, RS, Brasil. E-mail: paulastieven@yahoo.com.br. *Corresponding author.

\begin{abstract}
The aim of this study was to evaluate the morphology of endothelial cells from different areas of the cornea of dogs. Twenty healthy eyes from 10 dogs, females or males, of different ages were studied. Corneal endothelium morphology of superior, inferior, central, nasal and temporal areas was assessed by $0.2 \%$ alizarin red staining using an optic microscope. One hundred endothelial cells from each corneal area were analyzed. In all areas of the cornea studied were found endothelial cells with four sides, five sides, six sides and seven sides. There was no significant difference regarding endothelial cell morphology in all corneal regions evaluated. Thus, the morphology of the central cornea area represents the entire endothelial mosaic and may be applied to peripheral areas. Therefore, analysis of the central area is sufficient to estimate the shape of endothelial cells of peripheral areas of healthy dog corneas.
\end{abstract}

Key words: canine, cornea, endothelium, alizarin red, pleomorphism.

Morfologia das células endoteliais de diferentes regiões da córnea de cães

RESUMO: Objetivou-se avaliar a morfologia das células endoteliais de diferentes regiões da córnea de cães. Vinte olhos saudáveis de 10 cães, fêmeas ou machos, de diferentes idades foram estudados. A morfologia do endotélio corneano das regiões superior, inferior, central, nasal e temporal foi avaliada pela coloração vermelho de alizarina 0,2\% com microscópio óptico. Foram analisadas 100 células endoteliais de cada região da córnea. Em todas as regiões da córnea estudadas foram encontradas células endoteliais com quatro lados, cinco lados, seis lados e sete lados. Não houve diferença significativa em relação à morfologia de células endoteliais da córnea em todos as regiões estudadas. Assim, a morfologia da região central da córnea representa todo o mosaico endotelial e pode ser aplicada em áreas periféricas. Portanto, a análise da área central é suficiente para estimar a forma das células endoteliais das áreas periféricas de córneas de cães saudáveis.

Palavras-chave: canino, córnea, endotélio, vermelho de alizarina, pleomorfismo.

\section{INTRODUCTION}

The corneal endothelium is essential in maintaining the transparency of the cornea. Specular microscopy and confocal microscopy are employed for morphological and morphometric evaluation of endothelial cells in vivo (CANAVAGH et al., 2000; ABIB et al., 2012; NAGATSUYU et al., 2014; BERCHT et al., 2015). For in vitro and ex vivo studies, scanning electron microscopy (SEM) and optical microscopy are the most commonly used methods for endothelial evaluation (TAYLOR \& HUNT, 1981; COLLIN \& COLLIN, 1998; PIGATTO et al., 2005a; SAAD et al., 2008; PIGATTO et al., 2009; TERZARIOL et al., 2016). With these methods it is possible to estimate endothelial cell density, and morphology of endothelial cells. The evaluation of these parameters is an important indicator of corneal endothelium health. Alizarin red vital dye can be used for this qualitative and quantitative evaluation of corneal endothelium (TAYLOR \& HUNT, 1981; SAAD et al., 2008). The use of these vital dyes allows important studies to be carried out on endothelial alterations caused by drug toxicity, corneal healing, preservation of donor corneas and collection of corneal buttons for subsequent transplants, among other indications (AMANN et al., 2003; TERZARIOL et al., 2016). The morphological pattern of endothelial corneal cells is established in humans and some animal species (PIGATTO et al., 2008; FRANZEN et al. 2010; FAGANELLO et al., 2016). However, in animals normally the endothelial analysis is limited to the central region of the cornea (PIGATTO et al., 2004; MORITÁ et al., 1994; PIGATTO et al., 2005a; PIGATTO et al., 2006; PIGATTO et al., 2009; BERCHT et al.; 2015). 
The knowledge of the distribution of normal endothelial morphology is important not only to clinical evaluation but also to selection of areas of the cornea with better quality to be employed as donor tissue. In this article we intend to verify if it is possible to use the technique of vital dyes to stain the corneal endothelium of dogs. In addition, it was the objective of the study to evaluate if there are differences between the endothelium morphology in the different regions of the cornea of healthy dogs.

\section{MATERIALS AND METHODS}

Thirty eyes from 15 dogs, 14 males or 16 females, aged between two and four years were obtained from the Veterinary Pathology Service of the Universidade Federal do Rio Grande do Sul. These dogs were euthanized for reasons not related to this study and died of disease that did not directly affect the eye. This project was carried out following the norms of the Association for Research in Vision and Ophthalmology (ARVO) statement on the use of animals in ophthalmic and vision research. Examination of all eyes was performed before cornea collection and consisted of slit-lamp biomicroscopy (Portable Slit Lamp, Kowa SL15, Japan) and fluorescein staining (Fluorescein Strips, Ophthalmos, SP, Brazil). Only healthy eyes were selected. Enucleation was performed within four hours post-mortem, and the cornea and a $3.0 \mathrm{~mm}$ rim of sclera was removed, and with the endothelial side up, was transferred to glass laminae. The flatmounting technique was used for the preparation of the corneas (CLAESSON et al., 1997). Staining with $0.2 \%$ alizarin red (Alizarin Red S, Sigma-Aldrich, St. Louis, USA) was performed. The dye stayed in contact with the endothelium for 90 seconds and was washed three times with balanced salt solution. The posterior endothelial surface was examined, and photomicrographs were taken of central, superior, inferior, nasal and temporal corneal areas (Figure 1). Peripheral evaluations were performed about $2 \mathrm{~mm}$ from the limbus.

A light microscope (Nikon Eclipse E200, Japan) was used for analysis. Three random images from each corneal area were taken with X40 magnification. Microsoft's Paint software was used for image processing. By counting the number of sides of surrounding cells, 100 endothelial cells from each corneal area were evaluated. All analyses were performed by the same evaluator. The data were compared between areas and between right and left eyes by two-way analysis of variance (ANOVA) with a significance level of $\mathrm{P}<0.05 \%$.

\section{RESULTS}

With alizarin red staining and the use of optical microscopy it was possible to obtain images in all analyzed samples, as well as document and study

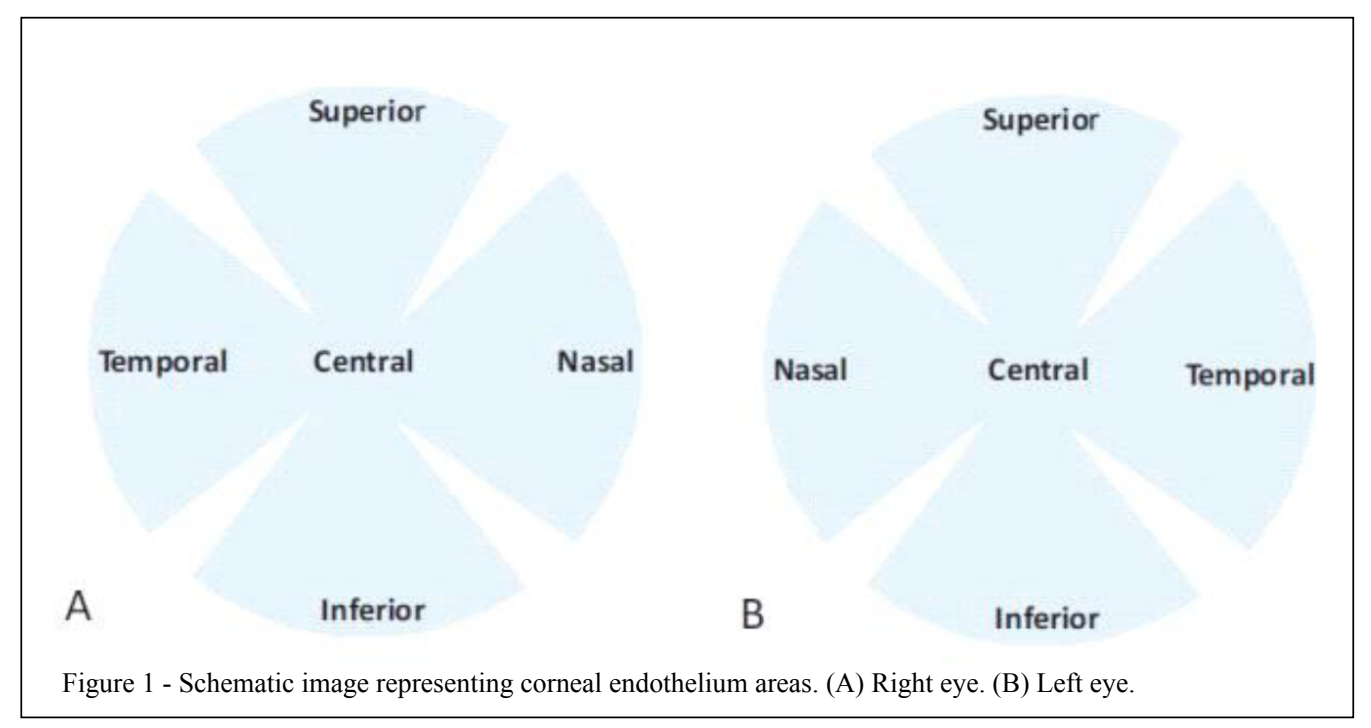

Ciência Rural, v.48, n.10, 2018. 
the morphology of endothelial cells from different corneal regions. Results of optical microscopy showed that the healthy corneal endothelium was composed of polygonal cells with a regular pattern, with a predominance of a hexagonal form.

Among the 30 corneas studied, the average percentage of hexagonal cells in the central area was $78.8 \pm 4.7 \%$ (Figure 2), in the superior area it was $79.4 \pm 4.9 \%$, in the inferior area it was $80.1 \pm 4.4 \%$ (Figure 3), in the temporal area it was $78 \pm 2.9 \%$ and in the nasal area it was $76.7 \pm 6.0 \%$ (Figure 4) $(\mathrm{P}=0.54)$. The average percentage of five-sided cells in the central area was $13.2 \pm 3.8 \%$, in the superior area it was $13 \pm 4.1 \%$, in the inferior area it was $11.7 \pm 3.5 \%$, in the temporal area of the left eye it was $13.2 \pm 3.8 \%$, and in the nasal area it was $14.1 \pm 4 \%(\mathrm{P}=0.67)$. The average percentage of seven-sided cells in the central area was $8.0 \pm 2 \%$, in the superior area it was $7.6 \pm 2.3 \%$, in the inferior area it was $8.2 \pm 3.2 \%$, in the temporal area it was $8.8 \pm 1.3 \%$, in the nasal area of the left eye it was $9 \pm 2.9 \%(\mathrm{P}=0.62)$. No significant difference was reported in the endothelial cell morphology of different areas of healthy canine corneas.

\section{DISCUSSION}

Vital staining with alizarin red and the use of optical microscopy is a quick, simple and inexpensive technique for obtaining images for evaluation of the endothelium of animals and humans (TAYLOR; HUNT, 1981; SAAD et al., 2008; FAGANELLO et al., 2016). However, none of these previously mentioned studies used the vital staining technique to evaluate the corneal endothelium of dogs. In this article, with alizarin red staining and the

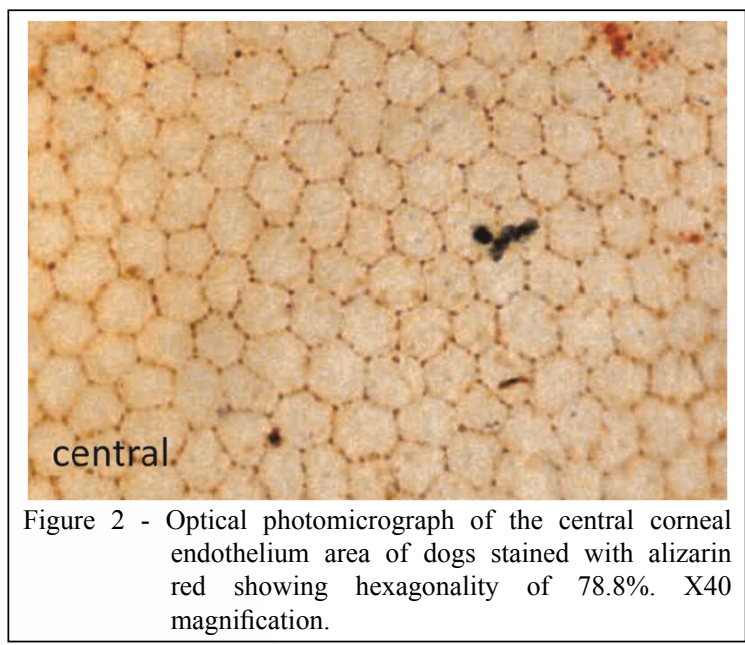

use of optical microscopy it was possible to analyze, study and document the morphology of endothelial cells from different areas of the corneal endothelium. Analysis of healthy canine corneal endothelium using $0.2 \%$ alizarin red allowed clear identification of cell borders and was possible to identify and to evaluate the number of sides of each endothelial cell. Previous experiments with the use of alizarin red in different concentrations and exposition times have been performed (ANDREW et al., 1999; PARK et al. 2012; FAGANELLO et al., 2016). Dual staining of corneal endothelium with vital dyes, using $0.2 \%$ alizarin red and $0.25 \%$ trypan blue, is the most frequently used technique for determining nonviable and viable cells in areas where cells cannot be identified with specular microscopy. Trypan blue penetrates damaged cell membranes while dying their nucleus blue and alizarin red dyes the edges of endothelial cells and the areas of cell loss where Descemet's membrane is exposed. In the current study the aim was to evaluate the morphology of normal dog corneas. Therefore, only the alizarin red dye was used with no need for association with trypan blue staining.

In the present study, gender was not was not considered as a variable. It is already well established in previous studies that there is no difference in endothelial parameters between males and females (FRANZEN, et al. 2010; BERCHT et al. 2015; ALBUQUERQUE et al. 2015).

GEROSKI and EDELHAUSER (1989) suggested caution when comparing morphometric data in vivo and in situ, as in their study with rabbit and human corneas comparing results of specular microscopy and vital staining there was considerable decrease in the cell area (14\%) of the endothelium of rabbit corneas stained with alizarin red, which led to increased endothelial density and a reduction in the variation of cell size. The morphology expressed by the hexagonal cell percentage was unchanged. In this sense, data related to endothelial morphology obtained with optical microscopy in the present study can be extrapolated for future clinical evaluations using specular microscopy in dogs. In order to obtain reproducible and reliable data, the number of cells to be counted has not been established. Some researchers recommend that at least 30 endothelial cells be counted, whereas others mention 50,75 or 100 cells by image (BOURNE et al., 1994; BERCHT et al. 2015). Each sampling process has an intrinsic error and a large number of cells counted generate a small sampling error (ABIB et al., 2012). In the present study, in order to reduce sampling and analysis errors, 100 endothelial cells were manually counted in each area of the cornea 

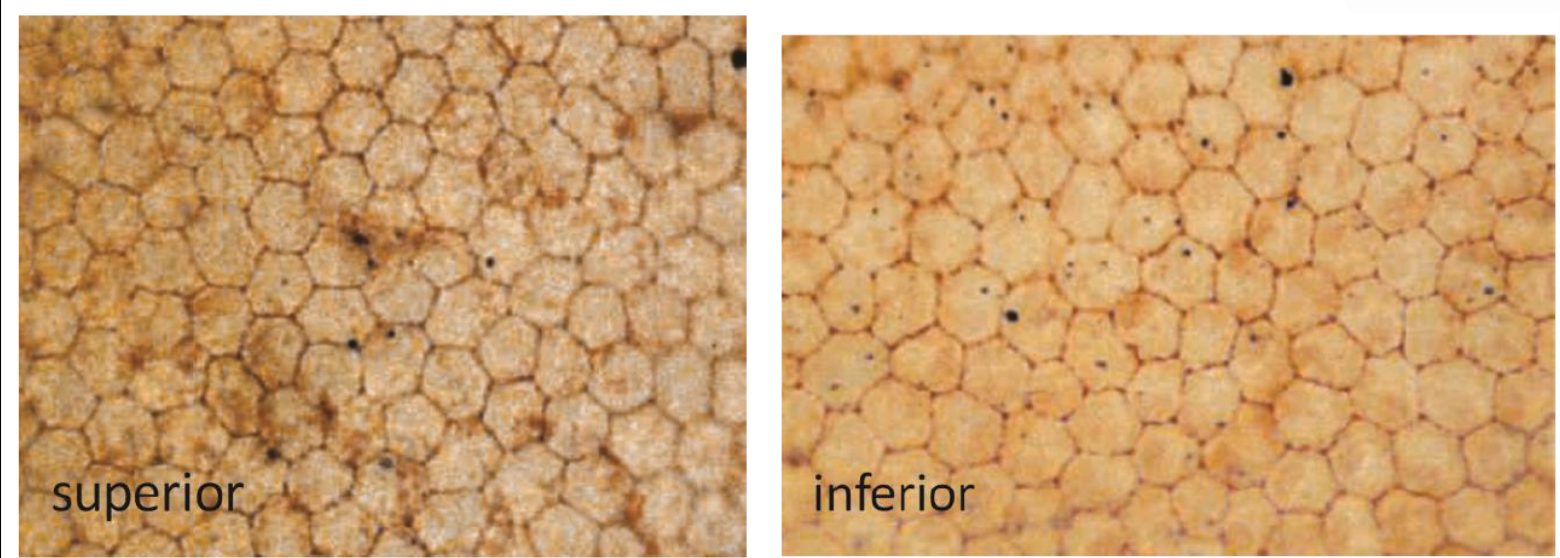

Figure 3 - Optical photomicrograph of superior and inferior corneal endothelium areas of dogs stained with alizarin red. The endothelium has a regular polygonal appearance with $79.4 \%$ hexagonal cells in the superior area and $80.1 \%$ in the inferior area. X40 magnification.

studied. This methodology has been used in previous studies (McCAREY et al., 2008; FAGANELLO et al., 2016). The enucleation and the maintenance of the eyes in a humid chamber allowed the examinations without interfering with the transparency of the corneal samples, which preserved their endothelial structure. This method has been used in other studies and proved to be effective (PIGATTO et al., 2004; PIGATTO et al., 2005a; PIGATTO et al, 2005b; FRANZEN et al., 2010; ALBUQUERQUE et al., 2015).

The flat-mounting technique allowed the cornea to be kept smooth and flat, preventing damage to the endothelium; although, some distortions are inevitable within the process and analysis (CLAESSON et al., 1997). Thus, this technique allowed the vital dye staining and the capture of images in all examined corneas.
Tamayo-Arango et al. (2009), assessing the corneal endothelium of pigs, established by SEM that most of the cells were hexagonal $(61.7 \pm 8.5 \%$ for the central area and $53.2 \pm 7.0 \%$ for the peripheral area), with the presence of pentagonal cells $(21.3 \pm 5.8 \%$ and $28.9 \pm 5.1 \%$ for the center and the periphery, respectively) and heptagonal cells $(11.0 \pm 6.4 \%$ for the center and $18.1 \pm 4.8 \%$ for the periphery). Moreover, there was no statistical difference between the central and peripheral cornea in relation to six- and seven-sided cells.

Regarding the endothelial cell density in dogs, previous studies have reported that there were no differences in endothelial cell density between central and peripheral corneal locations in healthy dogs (RODRIGUES et al., 2006). However, no analysis of the cellular morphology was performed in the different
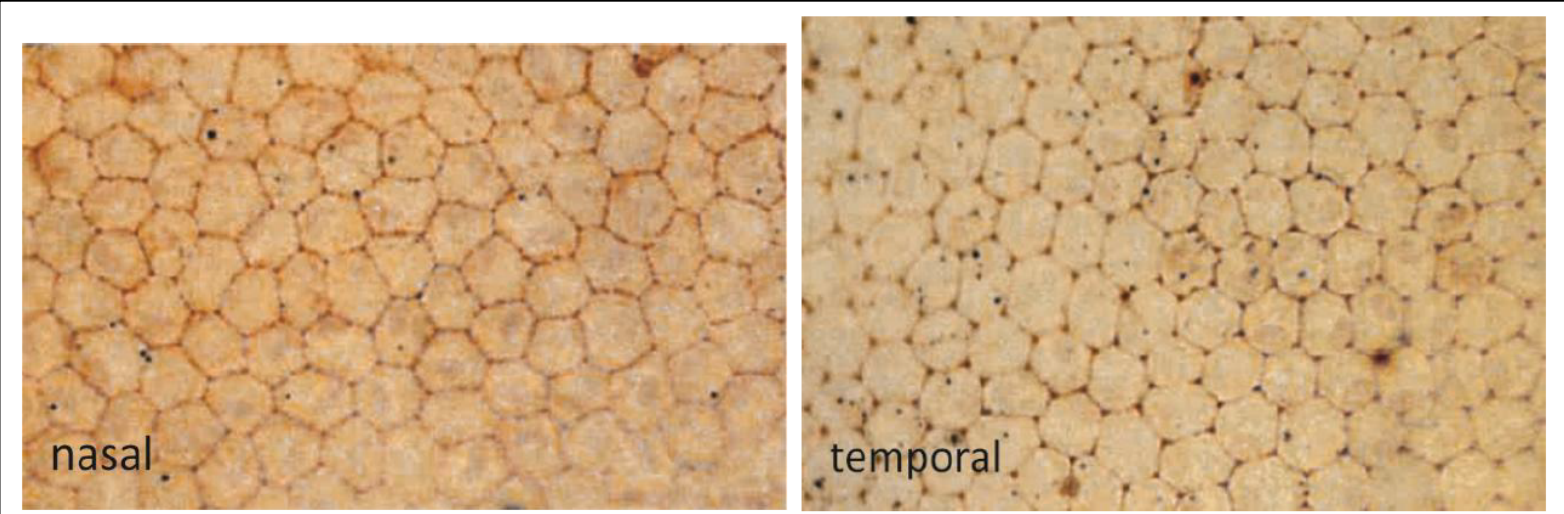

Figure 4 - Optical photomicrograph of nasal and temporal corneal endothelium areas of dogs stained with alizarin red. The endothelium has a regular polygonal appearance of $76.7 \%$ of hexagonal cells in the nasal area and $78 \%$ in the temporal area. X40 magnification. 
areas of the cornea of dogs. In the present study, the parameters evaluated did not differ significantly between the peripheral and central areas of corneas.

\section{CONCLUSION}

In all corneal areas studied, the endothelium of dogs had a similar morphology. Thus, the morphology of the central cornea area represents the entire endothelial mosaic and may be applied to peripheral areas. Therefore, analysis of the central area is sufficient to estimate the shape of endothelial cells of peripheral areas of healthy dog corneas.

\section{BIOETHICS AND BIOSSECURITY COMMITTEE APPROVAL}

This research was approved by the Research Committee of the Faculty of Veterinary of the Universidade Federal do Rio Grande do Sul (UFRGS), and followed the ethical norms of the Association for Research in Vision and Ophthalmology (ARVO).

\section{CONFLICTS OF INTEREST}

The authors declare no conflict of interest. The founding sponsors had no role in the design of the study; in the collection, analyses, or interpretation of data; in the writing of the manuscript, and in the decision to publish the results.

\section{AUTHORS' CONTRIBUTIONS}

The authors contributed equally to the manuscript.

\section{REFERENCES}

ABIB, F.C. et al. The endothelial sample size in corneal specular microscopy clinical examinations. Cornea, v. 31, n. 5, p. 546-550, 2012. Available from: <https://www.ncbi.nlm.nih.gov/pubmed/223333658>. Accessed: Mar. 07, 2017. doi: 10.1097/ICO.0b013e3181cc7961.

ALBUQUERQUE, L. et al. Analysis of the corneal endothelium in eyes of chickens using contact specular microscopy. Semina: Ciências Agrárias, Londrina, v.36, n.6, p.4199-4206, 2015. Available from: <http://www.uel.br/revistas/uel/index.php/semagrarias/article/ viewFile/19497/17540"19497/17540>. Accessed: Mar. 07, 2017. doi: 10.5433/1679-0359.2015v36n6Supl2p4199.

AMANN, J. et al. Increased endothelial cell density in the paracentral and peripheral regions of the human cornea. American Journal of Ophthalmology, v.135, n.5, p.584-590, 2003. Available from: $<$ http://dx.doi.org/10.1016/S0002-9394(02)02237-7>. Accessed: Nov. 20, 2015. doi: 10.1016/S0002-9394(02)02237-7.

ANDREW, S.E. et al. Comparison of Optisol-GS and neomycin poymyxin B-gramicidin ophthalmic solution for corneal storage in the dog. Veterinary Ophthalmology, v. 2, n. 3, p.155161, 1999. Available from: <https://europepmc.org/abstract/ med/11397258>. Accessed: Mar. 07, 2017. doi: 10.1046/j.14635224.1999.00070.x
BERCHT, B.S. et al. Specular microscopy to determine corneal endothelial cell morphology and morphometry in chinchilas (Chinchilla lanigera) in vivo. Veterinary Ophthalmology, v.18, n.1, p.137-142, 2015. Available from: <http://www.ncbi.nlm.nih.gov/ pubmed/25469785>. Accessed: Jul. 21, 2016. doi: 10.1111/vop.12236.

BOURNE, W.M. et al. Long-term observation on morphologic and functional features of cat corneal endothelium after wounding. Investigative Ophthalmology and Visual Science, v. 223 35, n. 3, p.891-899, 1994. Available from: <http://www.ncbi.nlm.nih. gov/pubmed/8125752>. Acessed: Mar. 07, 2017.

CLAESSON, M. et al. A method for separation and staining of flat mounts of human corneal endothelium. Acta Ophthalmologica Scandinavica, v. 75 , n. 2, p. 131-133, 1997. Available from: <http:// www.ncbi.nlm.nih.gov/pubmed/9197556>. Accessed: Mar. 07, 2017. doi: 234 10.1111/j.1600-0420.1997.tb00107.x.

FAGANELLO, C.S. et al. Morphology of endothelial cells from different regions of the equine cornea. Ciência Rural, v.46, n.12, p.2223-2228, 2016. Available from: <http://dx.doi. org/10.1590/0103-8478cr20160216>. Accessed: Mar. 20, 2017. doi: 10.5433/1679-0359.2015v36n6Sup12p4199.

FRANZEN, A.A. et al. Use of specular microscopy to determine corneal endothelial cell morphology and morphometry in enucleated cat eyes. Veterinary Ophthalmology, v.13, n.4, p.222-226, 2010. Available from: <http://hdl.handle.net/11449/41931>. Accessed: Oct. 04, 2016. doi: 10.1111/j.1463-5224.2010.00787.x.

GEROSKI, D.H.; EDELHAUSER, H.F. Morphometric analysis of the corneal endothelium. Investigative Ophthalmology and Visual Science, v. 30, n. 2, p. 254-259, 1989. Available from: $<$ http://www. ncbi.nlm.nih.gov/pubmed/2464555>. Acessed: Mar. 07, 2017.

McCAREY, B.E. et al. Review of corneal endothelial specular microscopy for FDA clinical trials of refractive procedures, surgical devices and new intraocular drugs and solutions. Cornea, v.27, n.1, p.1-16, 2008. Available from: <http://www.ncbi.nlm.nih.gov/ pmc/articles/PMC3062434/>. Acessed: Jan. 10, 2017. doi: 10.1097/ ICO.0b013e31815892da.

MORITÁ, H. Specular microscopy of corneal endothelial cells in cynomolgus monkeys. Journal of Veterinary Medicine and Science, v.56, n.4, p.763-764, 1994. Available from: <https://www. ncbi.nlm.nih.gov/pubmed/7999905>. Accessed: Sept. 11, 2016. doi: $10.1292 /$ jvms.56.763.

NAGATSUYU, C.E. et al. Non-contact specular microscopy in aphakic and pseudophakic dogs. Ciência Rural, v.44, n.4, p.682687, 2014. Available from: <http://dx.doi.org/10.1590/S010384782014000400018>. Accessed: Feb. 05, 2017. doi: 10.1590/ S0103-84782014000400018.

PARK, S. et al. Protocol for vital dye staining of corneal endothelial cells. Cornea, v. 31, n.12, p. 1476-1479, 2012. Available from: $<$ https://journals.lww.com/corneajrnl/Fulltext/2012/12000/Protocol_ for_Vital_Dye_Staining_of_Corneal.22.aspx $>$. Accessed: Mar. 07, 2017. doi: 10.1097/ICO.0b013e31824d0dda.

PIGATTO, J.A.T. et al. Morphometric analysis of the corneal endothelium of yacare caiman (Caiman yacare) using scanning electron microscopy. Veterinary Ophthalmology, v.7, n.3, p.205208, 2004. Available from: <http://www3.interscience.wiley.com/ journal/118811881/abstract/>. Accessed: Sept. 10, 2016. doi: 10.1111/j.1463-5224.2004.04025.x.

Ciência Rural, v.48, n.10, 2018. 
PIGATTO, J.A.T. et al. Análise morfométrica do endotélio corneano de coelhos à microscopia eletrônica de varredura. Acta Scientiae Veterinariae, v.33, n.1, p.33-39, 2005a. Available from: $<\mathrm{http}: / / \mathrm{www}$. redalyc.org/pdf/2890/289021867004.pdf >. Accessed: Oct. 11, 2016.

PIGATTO, J.A.T. et al. Corneal endothelium of the magellanic penguin (Spheniscus magellanicus) by scanning electron microscopy. Journal of Zoo and Wildlife Medicine, v.36, p.702-705, 2005b. Available from: <http://www.bioone.org/doi/abs/10.1638/05017.1>. Accessed: Oct. 10, 2016. doi: 10.1638/05017.1.

PIGATTO, J.A.T. et al. Density of corneal endothelial cells in eyes of dogs using specular microscopy. Brazilian Journal of Veterinary Research and Animal Science, v.43, n.4, p.476-480, 2006. Available from: <http://www.uel.br/revistas/uel/index.php/ semagrarias/article/viewFile/19497/17540>. Acessed: Mar. 14, 2016. doi: 10.5433/1679-0359.

PIGATTO, J.A.T. et al. Morphological analysis of the corneal endothelium in eyes of dogs using specular microscopy. PesquisaVeterinária Brasileira, v.28, n.9, p.427-430, 2008. Available from: $<$ http://www.scielo.br/scielo.php?pid=S0100736X2008000900006\&script $=$ sci_arttext\&tlng=pt $>$. Accessed: Sept. 07, 2016. doi: 10.1590/S0100.

PIGATTO, J.A.T. et al. Scanning electron microscopy of the corneal endothelium of ostrich. Ciência Rural, v.39, n.3, p.926929, 2009. Available from: <http://dx.doi.org/10.1590/S010384782009005000001>. Accessed: Oct. 21, 2016. doi: 10.1590/ S0103-84782009005000001.

RODRIGUES, G.N. et al. Corneal endothelial cell morphology of normal dogs in different ages. Veterinary Ophthalmology, v.
9, n. 2, p. 101-107, 2006. Available from: <http://www.ncbi.nlm. nih.gov/pubmed/16497234>. Accessed: Mar. 07, 2017. doi: 315 10.1111/j.1463-5224.2006.00427.x.

SAAD, H.A. et al. An easy and inexpensive method for quantitative analysis of endothelial damage by using vital dye staining and adobe photoshop software. Cornea, v.27, p.818-824, 2008. Available from: $<$ http://journals.lww.com/corneajrnl/Abstract/2008/08000/An_Easy_ and InexpensiveMethod_for_Quantitative.13.aspx $>$. Accessed: Oct. 12, 2016 . doi: $10.1097 / \mathrm{ICO} . \overline{\mathrm{b}} 013 \mathrm{e} 3181705 \mathrm{ca} 2$.

TAMAYO-ARANGO, L.J. et al. Ultrastructural morphology and morphometry of the normal corneal endothelium of adult crossbred pig. Ciência Rural, v.39, n.1, p.117-122, 2009. Available from: $<$ http://dx.doi.org/10.1590/S0103-84782009000100018>. Accessed: Mar. 08, 2016. doi: 10.1590/S0103-84782009000100018.

TERZARIOL, M. et al. Effects of intracameral brilliant blue on the corneal endothelium of swine: in vitro study. Pesquisa Veterinária Brasileira, v.36, n.8, p.775-780, 2016. Available from: <http:// dx.doi.org/10.1590/S0100-736X2016000800016>. Accessed: Nov. 21, 2016. doi: 10.1590/S0100-736X2016000800016.

TAYLOR, M.J. \& HUNT, C.J. Dual staining of corneal endothelium with trypan blue and alizarin red S: importance of $\mathrm{pH}$ for the dye-lake reaction. British Journal of Ophthalmology, v.65, p.815-819, 1981. Available from: <http://bjo.bmj.com/ content/65/12/815>. Accessed: Dec. 18, 2016. doi: 10.1136/ bjo.65.12.815.

TUFT, S.J.; COSTER, D. J. The corneal endothelium. Eye, v. 4, p. 389-424, 1990. Available from: <http://www.ncbi.nlm.nih.gov/pubmed/2209904>. Accessed: Mar. 07, 2017. doi: 346 10.1038/eye.1990.53. 